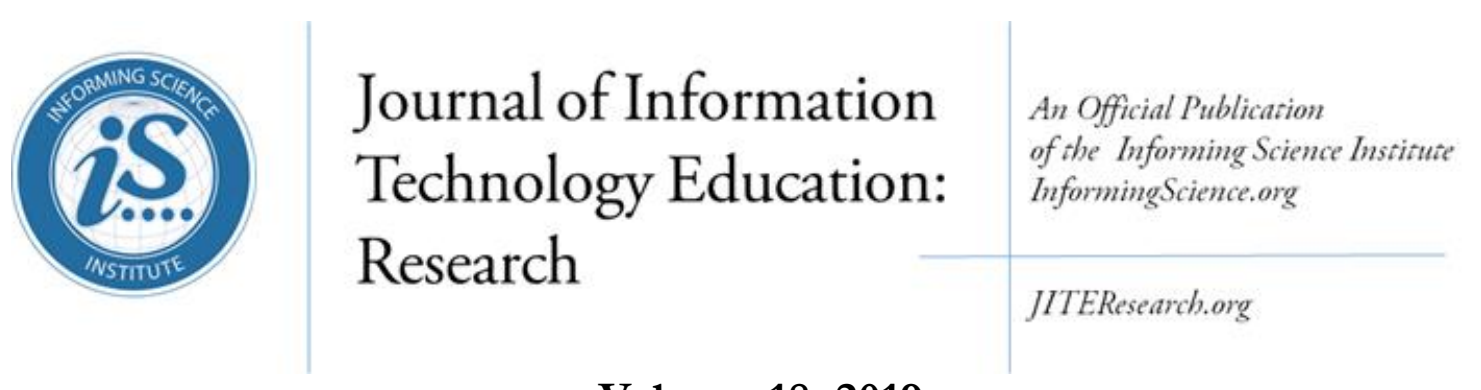

Volume 18, 2019

\title{
TECHNOLOGY SUPPORT, SOCIAL SUPPORT, ACADEMIC SUPPORT, SERVICE SUPPORT, AND STUDENT SATISFACTION
}

Praveen Kakada*

Yogesh Deshpande

ShilpaBisen

* Corresponding author
Visvesvaraya National Institute of Technology, Nagpur, India

Visvesvaraya National Institute of Technology, Nagpur, India

Visvesvaraya National Institute of Technology, Nagpur, India praveenkakada@gmail.com

drymdeshpande@gmail.com

Shilpabisen777@gmail.com

\section{ABSTRACT}

Aim/Purpose

Background

Methodology

Contribution
The study aimed to investigate the influence of technology support, social support, academic support, and service support on student satisfaction and their relationships in private and state universities.

Coherent support between students, teachers, and management is usually extended beyond classroom scheduling and space. This support has a positive significant influence on student satisfaction, which may influence students' academic, behavioral, emotional and social development. This support is assisted via technology, social, academic, and instant service support, which may have an impact on its nature.

In the current study, a cross-sectional survey was used to collect the research data. Convenience sampling was used to select the participants for the study. It targeted a population sampled from engineering students from both private and state universities of central India $(n=240)$. In quantitative data analysis, descriptive and inferential statistics were used. The collected data were analyzed with SPSS.

The present study expands the growing body of knowledge about student satisfaction via technology, social, academic, and service support. We identify the unique aspects of factors that are positively related to student satisfaction, which shed light on student satisfaction. Findings from this study may assist educators (while in training and/or professional development programs) to

Accepting Editor Man Fung (Kelvin) LO | Received: August 14, 2019 | Revised: September 29, October 16, October 24, November 1, November 10, 2019 | Accepted: November 12, 2019.

Cite as: Kakada, P., Deshpande, Y., \& Bisen, S. (2019). Technology support, social support, academic support, service support, and student satisfaction. Journal of Information Technology Education: Research, 18, 549-570. https://doi.org/10.28945/4461

(CC BY-NC 4.0) This article is licensed to you under a Creative Commons Attribution-NonCommercial 4.0 International License. When you copy and redistribute this paper in full or in part, you need to provide proper attribution to it to ensure that others can later locate this work (and to ensure that others do not accuse you of plagiarism). You may (and we encourage you to) adapt, remix, transform, and build upon the material for any non-commercial purposes. This license does not permit you to use this material for commercial purposes. 
Findings

Recommendations for Practitioners

Recommendations for Researchers

Impact on Society

Future Research

Keywords reflect upon their educational strategies to enhance the level of satisfaction among the students and to check how their students can benefit from the support system in the institution.

The results indicated that the institutional support dimensions -technology support, academic support, social support, and service support -are positively significantly related to student satisfaction in both state and private universities.

As a result of the study, it is recommended to university policymakers and administrations to provide and emphasize the importance of institutional support. In addition, it is recommended to provide students with knowledge that focuses on technology, academic, social, and other related service support. Doing so can provide valuable insight into students' level of satisfaction enhancement with institutional support.

Researchers need to start factoring in how institutional support and services influence student satisfaction. Findings will further enrich the literature on student satisfaction in higher educational institutions. This study should be simulated to more populations and other geographical areas, to validate its findings.

Improvement in our understanding of technology, social, academic, and other services helps to improve the quality of instruction, which provides a net gain for society. If this support system is to be carried out properly, the students, who are the future citizens - will learn how to behave appropriately in the digital age.

This paper is a broad overview using a survey, so future research should focus on a more detailed analysis of the consequence of student satisfaction, possibly using controlled experiments. In addition, qualitative exploration is advisable, as it may shed more light on the unique aspects of factors that are related to student satisfaction.

technology support, academic support, social support, service support, student satisfaction

\section{INTRODUCTION}

Higher education institutions are progressively recognizing more that higher education is a service industry and are placing greater importance on meeting the expectations and requirements of their participating customers, that is, the students. The rapid increase of universities and colleges, changes in social and demographic trends, globalization, and competitive advantage market motivate the toplevel authority to think about the sustainability of educational institutions. To run the educational institutions long-term in this competitive and demanding environment, satisfying the major stakeholder (students) is very essential (Kotler \& Fox, 1995). The students' expectations and the demands of the education community are changing radically over the last few decades. Previous studies specify that satisfied students will be more productive and successful (Cotton, Dollard, \&De Jonge, 2002).

In addition to this, there is another study that suggested that students who are satisfied with their undergraduate education are more successful in their future endeavor (Ostergaard \& Kristensen, 2005). Large-scale European studies show that satisfied students are more capable of entering and competing in the global workplace. Therefore, student satisfaction matters before and after graduation and affects the current and future quality of life (Vaatstra \& De Vries, 2007). So today's educational institutes are striving to build a distinct image to maintain their competitiveness in the market (Aroury, Daou, \& Khoury, 2014). Student satisfaction has been recognized as a central concept of all 
academic activities. Satisfaction can serve as an indicator of the success of many educational institutes, both in the past and in present, which is an indicator of future accomplishment. High-quality service to students is a prerequisite for maintaining competitiveness in the market for higher education.

Moreover, earlier studies(Alzamel, 2014;Priya, Bhadouria, \& Charu, 2013) concluded that quality of education, cost of education, nature of the learning environment, the reputation of the institute, facilities, staff assessment and delivery of service, and recognition of the institution have an influence on student satisfaction. On the other hand, other authors have stated that socio-economic factors, parent's educational background income (Astin \& Oseguera, 2005), financial problems (Astin \& Oseguera, 2005; Yorke \&Thomas, 2003), and social life (Roberts \& Styron, 2010) are contributing to student satisfaction. In educational institutions, academic support plays a significant role in student satisfaction because satisfaction positively influences student decision-making, motivation, and academic performance. Positive word of mouth will attract prospective students as well.

Successful educational institutions identified the factors that enhance student satisfaction and realized that it is better to invest at the onset to retain their students (Elliott \& Shin, 2002). Elliott and Shin (2002) identified some dimensions which determine student satisfaction, such as quality of classroom interactions, relationship with faculty, positive feelings about their classroom and social interactions, and a sense of fitting in with the campus culture. A significant relationship exists between student satisfaction, retention, and institutional goals (Schertzer \& Schertzer, 2004). Several research studies emphasized that departmental culture and climate have significantly determined student learning and satisfaction (Umbach \& Porter, 2002).

As students attempt to reach higher levels of education, institutional support becomes increasingly important to satisfy their academic and individual needs. Therefore, it is important to investigate higher education students' perceptions towards institutional support and satisfaction and to find out the relationship between them. As such, this research study attempts to understand the correlation between institutional support and student satisfaction. This study will look into how institutional support contributes to the academic development of both the student and the educational institution.

There are three research questions to be answered in this study.

1. What are the factors that are contributing to institutional support and its influence on students?

2. Which variable occupies more importance in explaining student satisfaction in state and private university?

3. Is there a relationship between institutional support and student satisfaction?

\section{LITERATURE REVIEW}

A model proposed by Astin (1991), the Input - Environment - Output model, explained that a student's dimensions, such as individual attributes, experience, and family background, affect the student's intentions, goals, and commitments to the institution (Yorke \& Thomas, 2003). It is understandable that the reason why contact with the teaching faculty seems to play an important role. Elliot's (2002) argument proved that the quality of education was one of the important factors in explaining student satisfaction with education institutions.

\section{ACADEMIC SUPPORT}

Academic support enhances personal confidence and status, which helps the students to succeed and to retain stable knowledge in their future life. Sufficient physical facilities, which include textbooks, libraries, teaching materials, and learning, are one of the factors that facilitate students toward academic success (Harmon \&Wales, 1999). The research found that there is a clear relationship present 
Technology Support, Social Support, Academic Support, Service Support, and Student Satisfaction

between satisfaction with the quality of teaching and academic support (Elliot, 2002; Kara \& DeShields, 2004). The authors highlighted the role of faculty accessibility in increasing student satisfaction and positive feelings about the university. Lipka, Forkosh, and Meer (2019) studied postsecondary school students with learning disabilities; results indicated that academic support enhances the learning ability, which in turn leads to student satisfaction. Effective coaching appears to be positive, particularly for coaches or mentors who regularly contact students to provide academic support (Bettinger \& Rachel, 2014).

Rittschof and Chambers (2011) found that modern measurement information graphs are useful to understand and identify accuracy and confidence in the relative differences among students' performance. Academic support shows a positive relationship with student satisfaction, which leads to build up a trust towards the educational institutions (Chen, \& Macredie, 2004). Martirosyan, Saxon, and Wanjohi (2014) emphasize a strong positive significant relationship between student satisfaction and academic support. As a part of academic support, such as co-curricular related activities and foreign language courses offerings on the campus, have a significant influence on student satisfaction (Ozudogru \& Hismanoglu, 2016). Roberts and Styron (2010) found that those students who did not return to university had statistically significant lower perceptions of faculty approachability than those that remained in their course.

H1: Academic support positively and significantly affects student satisfaction in both state and private universities.

\section{SOCIAL SUPPORT}

Social support is one of the important and essential focuses of transitional studies these days. Social support is an essential element which regularly is used in a great deal of socio-psychological and socio-educational research (Awang, 2012; Demaray, Malecki, Davidson, Hodgson, \& Rebus, 2005). Lin (2010) defined it as an involvement with other people that brought students insight, positive learning experiences. Demaray et al. (2005) conceptualize 'social support' as "transpiring from multiple sources teachers, parents, close friends, classmates, and multiple types informational, appraisal, emotional which enhance student satisfaction.

Bean (2005) views that social support from close friends and associates of educational institutions builds social integration. Social support enhances interpersonal and inter-group interactions (Topping \& Foggie, 2010). The student experience was positively associated with their academic success, and specifically, there was a positive relationship found between social support and student satisfaction (Saenz Marcoulides, Junn, \& Young, 1999). Social support from peers or family members, and wellbeing, are positively related to student satisfaction (Awang, Kutty, \& Ahmad, 2014; Pluut, Curşeu, \&Ilies, 2015). Ozben (2013) noted that students reported higher levels of satisfaction when a campus environment has a strong social life. The quality of life improves when students are integrated into the social atmosphere on the campus. Further, Denson and Zhang (2010) believe that engaging students in various social activities contributes to the development of student positive attitude. A lack of social skills can have a significant impact on multiple aspects of an individual's life by increasing the complexity intrinsic in advocating for oneself, managing expectations of autonomy and selfreliance, and building and continuing friendships. Therefore, a university must play an important role in providing students with the opportunity to develop their social life and to practice social integration as they learn and grow.

H2: Social support positively and significantly affects student satisfaction in both state and private universities. 
Kakada, Deshpande, \& Bisen

\section{TECHNOLOGY SUPPORT}

Nowadays, digital technology plays an important role in higher education. Student and faculty members have an opportunity to use digital technologies widely, potentially due to advancements in technology and competitiveness in higher education. The use of technology as a teaching and learning environment in education enables academic staff to be innovative in integrating technology in their research activities and teaching, although over usage of technology may lead to disruption in study routines and academic grading (Bisen \& Deshpande, 2018). Educational institutions libraries must be equipped with new teaching technologies and new electronic information sources including databases, journals, up-to-date textbooks, periodicals advanced multimedia resources, liquid crystal display projectors computer labs, high-speed Internet access, visual and audio equipment to facilitate student learning which in turn leads to satisfaction (Heyneman, 2001).

Engaging the students in digital learning is becoming a priority for many educational institutions and has created a number of approaches: flipped classroom (McLaughlin et al., 2014), student-centered learning (Baeten, Kyndt, Struyven, \& Dochy, 2010), and learning mediated by technology (Price \& Kirkwood, 2011). Technology-driven instruments and apparatus have a strong influence on student satisfaction (Gilboy, Heinerichs, \& Pazzaglia, 2015). Further, using technology-based measurement and applications, which encouraged student engagement in return, enhances the level of satisfaction (Hepplestone, Holden, Irwin, Parkin, \& Thorpe, 2011). Reliable facilities and equipment must be accessible to students; otherwise, it can affect their learning environment (Belanger \& Jordan, 2000). Technology support and special learning needs are now meeting the student's goals more quickly due to this technology integration. Technology support and special learning needs are now meeting the student's goals more quickly and enhance their level of satisfaction (Courduff, 2011).

H3: Technology support positively and significantly affects student satisfaction in both state and private universities.

\section{SERVICE SUPPORT}

Service support has received an immense deal of attention in current educational literature because of its multidimensional approach, nature and its eventual influence on individual satisfaction, behavioral loyalty, and ultimately, educational institution success (Paul\& Pradhan, 2019). Grönroos (1984) believed that service quality is made up of three dimensions "the technical quality of the outcome", "the functional quality of the encounter" and "the company corporate image." He argued that in investigating the dimensions of quality, it is essential to distinguish between quality related to the process of service, delivery, and quality associated with the outcome of service support, judged by the consumer after the service is performed.

Smith and Ennews' (2001) study outlined specific supportive items known as university facilities, such as cafeterias, residential accommodation, washroom hygienic, canteen and health clubs, which directly and indirectly have a significant impact on the evaluation of the university. Several studies have shown that providing text, email, and phone call reminders to parents about their children's progress in academics boosts both parental engagement and student academic success (Kraft \& Dougherty, 2013). Standardized quality services provided by the higher educational institutions increase the level of student satisfaction (Wilkins, Stephens, \& Huisman, 2012). Service support positively and significantly relates to student satisfaction (Oldfield \&Baron, 2000). Better service support determines the success in student e learning, where the role of institutional support has greater importance in explaining satisfaction (Ayuni \& Mulyana, 2019). This study supports the notion that those educational institutions providing higher education can achieve a competitive advantage by focusing on service support.

H4: Service support positively and significantly affects student satisfaction in both state and private universities. 


\section{STUDENT SATISFACTION}

Satisfaction covers issues of students' perceptions and experiences during the university years (Carey, Cambiano, \& De Vore, 2002). O'Neill and Palmer (2004) define student satisfaction as the difference between students' expectations of what they will get from a higher education institution and their realized expectations. Researchers are facing a problem of creating a standard definition for student satisfaction, thus providing a need for customer satisfaction theory to be selected and personalized so that it can elucidate the meaning of student satisfaction (Hom, 2002). Even though it is difficult to view a student as a customer, given the current atmosphere of the higher education marketplace, students have become customers (Bunce, Baird, \& Jones,2017); therefore as fee payers, they realistically demand that their views be heard and acted upon (William, 2002).

Most of the student satisfaction studies focus on the perspective of the customer. A study, which took place in a university campus environment, revealed that evaluation of service quality and facilities leads to student satisfaction. There was no evidence to support the opposite relationship Ekinci (2003). Satisfaction of customers is regarded as a strong tool for the attainment of competitive advantage in any business atmosphere (Alzamel, 2014). Satisfied students are more productive, confident, and resourceful in their academic and life endeavour (Rode et al., 2005). Institutional support and academic activities determine student satisfaction (Loveland \& Bland, 2013). According to DeShields, Kara, and Kaynak(2005) skills developed such as critical thinking and moral awareness along with preparation for the future are important factors influencing student satisfaction.

There are some factors which significantly contribute student satisfaction, such as faculty support (Umbach \& Porter, 2002), assessment and feedback, cost of education, social life (Alzamel, 2014; Wilkins et al., 2012), student learning (DeShields, Kara, \&Kaynak, 2005), canteen (Priya, Bhadouria \& Charu Shri, 2013), computer laboratory and class schedules (Loveland \& Bland, 2013), the reputation of a university (Alzamel, 2014), and Co-curriculum (Bergmark \& Westman, 2016). Increasing student satisfaction enhances students' motivation, as well as their attendance (Navarro, Iglesias, \& Torres, 2005; Schertzer \& Schertzer, 2004). Administrative staff also plays a significant role in the process of meeting students' demands (Nyer, 2000). Active learning methods are related to greater student satisfaction (Gulley \& Jackson, 2016; Roach, 2014).

The original proposed model for the current study is illustrated in Figure 1. The proposed model for this current study focuses on how the influence of academic support, social support, technology support, and service support enhances the level of student satisfaction. The proposed model for the present study is congruent with the previous study done by Kakada \& Deshapande (2019) where they extended the theoretical understanding of supervisor support and work environment, which enhance the faculty job satisfaction.

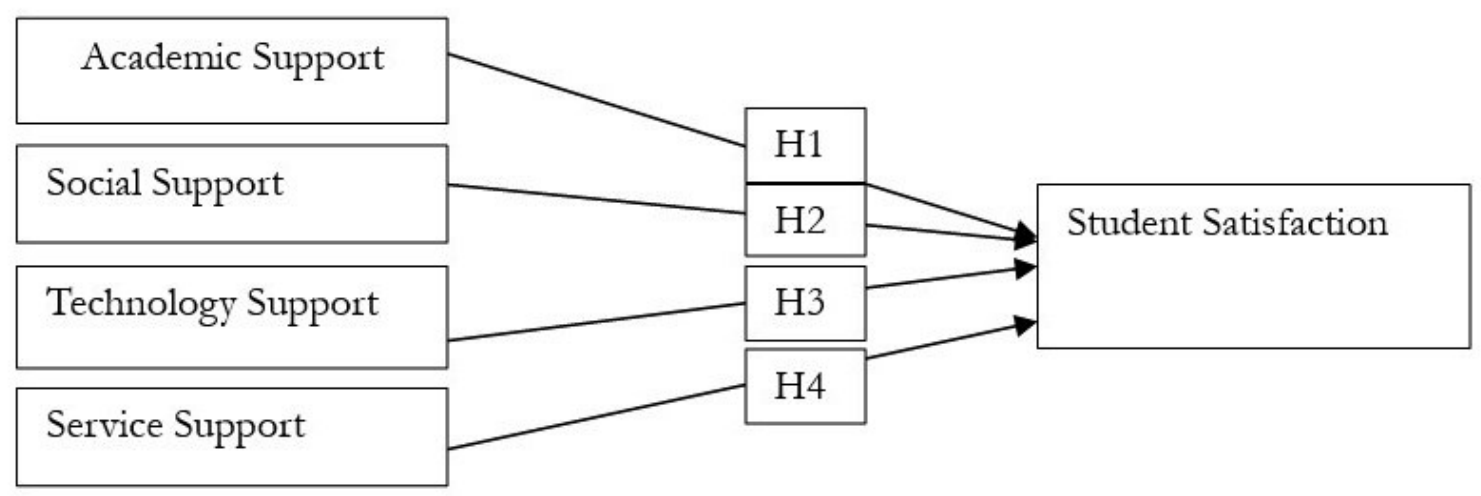

Figure 1: Proposed model for the study 
Kakada, Deshpande, \& Bisen

\section{METHODS}

\section{RESEARCH DESIGN}

Accordingly, a survey research approach was adopted here as the most effective means of meeting the present research objective. The survey research design is defined as "acquiring information about one or more groups of people - perhaps about their characteristics, opinions, attitudes, or previous experiences by asking them questions and tabulating their answers" (Leedy \& Ormrod, 2001, p.183). Surveys were considered as the most effective element for collecting the research data, based on the principle that they can assist researchers to focus on estimating variables with greater accuracy (Saunders, Lewis, \& Thornhill, 2009). Furthermore, a questionnaire approach was adopted to identify undergraduate students' perceptions of the validity of the research components, using a research questionnaire adapted from earlier studies.

\section{SAMPLING}

The present study was conducted on engineering students from both private and state universities of central India. Engineering students were taken as the sampling frame for this study. Based on the government's database, total state and private university students in central India was approximately 102,223 students. With the assumption that 51 percent (Ministry of Human Resource Development [MHRD], 2018) of these engineering students, the size of the target, the population was predicted to be about 52,000. With a 5 percent margin of error, the sample size for this study should be at least 190 (Denscombe, 2010). Therefore, the sample size in this study (240) satisfied the minimum requirement for valid statistical analysis.

To select the participants for the current study a convenience sampling technique was used. According to Muijs (2011), this method is one of the most accepted sampling approaches even though it has some limitations because of its subjective nature, convenience sampling assists researchers in choosing respondents according to their accessibility (Tarhini, Hone, \& Liu, 2015), and readiness to participate (Etikan, Musa, \& Alkassim, 2016). In addition, it is helpful to the researchers when they have inadequate resources, time, and the population is quite large. Overall, the research sample comprised 240 engineering students, from state and private university who were aware of institutional support and services. In total, the response rate was approximately $81.6 \%$, as the questionnaire was distributed to around 310 university undergraduates. Out of those responded questionnaires, 240 questionnaires were valid for study. The specialization of the participants was from different departments, such as electrical, mechanical, civil, applied mechanic, and information technology.

\section{MEASURES}

The student satisfaction survey scale was developed by Pareek and Purohit (2018) with Cronbach's alpha (0.961). Example items: 'My academic advisor helps me to set goals' and 'I feel a sense of pride about my campus'. The Institutional support scale was developed by the researcher for a clear understanding of research constructs. This questionnaire was designed based on constructs defined in the current literature and previous studies (Bolliger, 2004; Sahin \& Shelley, 2008). The instrument was piloted before the data collection phase and had an internal reliability coefficient of (0.924). It consisted of 21 items measuring four dimensions.

First variable academic support with 6 items, example item: 'My Institute provides financial support/sponsor for attending workshops, national and international conference and academic events' and 'My Institute provides industrial visit/guest lecturer for practical exposure and industrial training' with Cronbach's alpha 0.891.

Second variable technology support with 6 items, for example, item: 'My institute has its dynamic website to view/share academic notifications, news updates and announcements' and 
Technology Support, Social Support, Academic Support, Service Support, and Student Satisfaction

'My institute provides free access to online journals on campus to study' with Cronbach's alpha 0.841 .

Third variable social support with 3 items, example item: 'High inter-departmental collaboration exists in our university' and 'Institute encourage us by giving rewards, recognition and meritorious scholarship for excellence in academics' with Cronbach's alpha 0.786.

Fourth variable service support with 3 items, example item: 'Institute provides placement related soft skill programs to enhance our technology and personnel skills' and 'Institute offers a course to learn a foreign language' with Cronbach's alpha 0.798 .

Cronbach's coefficient alpha is the most frequently used technique for ensuring the reliability of a questionnaire (Pallant, 2013). A Cronbach's alpha value of more than 0.70 indicates the better reliability of the construct (Bryman, 2008). Based on this threshold, the research questionnaire constructs in this current study attained an acceptable level of reliability, with alphas ranging from 0.78 to 0.96 for both the questionnaire. A 5-point Likert scale was used to evaluate the answers for both scales ranging from 5 (strongly agree) to 1 (strongly disagree) for all the items. Data entry, processing, and analysis were undertaken in SPSS 20. This questionnaire is presented in the appendix.

\section{DATA COLLECTION PROCEDURES}

After identifying and selecting the participants, the questionnaire was distributed in a paper-based form. Researchers choose paper-based form rather than online form because according to Nulty (2008), "online surveys are much less likely to achieve response rates as high as surveys administered on paper" (p. 302). Respondents were informed about the purpose of conducting this study and assured anonymity. Purposely, they were informed that individual responses would not be shared with anyone in the Institute; the data would be used solely for research purposes. Questionnaires were distributed by the researcher to the students directly, were given time to complete the surveys, and were asked to return the filled questionnaire to the researcher. In general, each respondent took approximately 20 minutes to complete the questionnaire. Finally, all the data were collected and prepared for quantitative data analysis.

\section{DATA ANALYSIS AND RESULTS}

Table1: Demographic variables

\begin{tabular}{|l|l|l|}
\hline Category & Frequency & Percentage \\
\hline University & 120 & 50 \\
\hline State & 120 & 50 \\
\hline Private & 156 & 65 \\
\hline Gender & 84 & 35 \\
\hline Male & \multicolumn{2}{|l|}{} \\
\hline Female & 240 & 100 \\
\hline Qualification & Engineering students
\end{tabular}

Table 1 shows the demographic statistics for the research subjects. All respondents were undergraduate students from a state university and private university of central India. Out of 240 respondents, 120 students were from the state university and 120 students from the private university. Gender differences from the total participants were 65\% (156 respondents) male and 35\% (84 respondents) female. 
Table 2: Mean, standard deviation and correlation

\begin{tabular}{|l|l|l|l|l|l|l|l|}
\hline Variables & Category & Mean & SD & TES & ACS & SOS & SES \\
\hline \multirow{2}{*}{ TES } & State University & 3.17 & 0.74 & & & & \\
\cline { 2 - 9 } & Private University & 2.99 & 0.65 & & & & \\
\hline \multirow{3}{*}{ ACS } & State University & 3.52 & 0.79 & $102^{* *}$ & & & \\
\cline { 2 - 9 } & Private University & 2.97 & 0.62 & $.505^{* *}$ & & & \\
\hline \multirow{3}{*}{ SOS } & State University & 2.72 & 0.97 & $.176^{* *}$ & $.382^{*}$ & & \\
\cline { 2 - 9 } & Private University & 2.45 & 1.01 & $.324^{* *}$ & $.396^{* *}$ & & \\
\hline \multirow{2}{*}{ SES } & State University & 3.28 & 0.72 & $.775^{* *}$ & $.129^{* *}$ & $.283^{* *}$ & \\
\cline { 2 - 9 } & Private University & 2.77 & 0.76 & $.150^{* *}$ & $.332^{* *}$ & $.256^{* *}$ & \\
\hline \multirow{2}{*}{ STS } & State University & 3.05 & 0.46 & $.548^{* *}$ & $.690^{* *}$ & $.745^{* *}$ & $.514^{* *}$ \\
\cline { 2 - 9 } & Private University & 2.81 & 0.71 & $.685^{* *}$ & $.812^{* *}$ & $.712^{* *}$ & $.589^{* *}$ \\
\hline
\end{tabular}

**.Correlation is significant at the 0.01 level (2-tailed) TES=Technology Support; ACS = Academic Support; SOS = Social Support; SES = Service Support; STS $=$ Student Satisfaction.

The coefficient of correlation measures the relative strength of a linear relationship between two numerical variables and the existence of a strong correlation does not imply a causation effect. It only indicates the tendencies present in the data. To check the causation effect the hypotheses were tested using a multiple regression analysis, which can be used to analyze the relationship between a single dependent (criterion) variable and several independent (predictor) variables at one time. In this analysis, a set of independent variables are weighted to form the regression variate (regression equation or model) that may be used to explain their relative contributions to one dependent variable (Berenson, Levine, Szabat, \& Krehbiel, 2012). The data in Table2 shows that technology support has a positive correlation with student satisfaction in both universities of state $(\mathrm{r}=0.55)$ and private $(\mathrm{r}=$ 0.69). Academic support has a positive correlation with student satisfaction in both universities of state $(r=0.69)$ and private $(r=0.81)$. Social support has a positive correlation with student satisfaction in both universities of state $(r=0.75)$ and private $(r=0.72)$. Service support has a positive correlation with student satisfaction in both universities of state $(\mathrm{r}=0.55)$ and private $(\mathrm{r}=0.59)$. All the dimensions have strong correlation with student satisfaction; out of those, academic support in private university has shown a slightly strong correlation with student satisfaction whereas in-state university social support has shown a slightly stronger correlation with student satisfaction compared to other dimensions.

Table 3: Independent Samples t-test

\begin{tabular}{|c|l|c|c|c|c|c|}
\hline \multicolumn{2}{|c|}{} & \multicolumn{2}{c|}{$\begin{array}{c}\text { Levene's Test for } \\
\text { Equality of Variances }\end{array}$} & \multicolumn{3}{c|}{ t-test for Equality of Means } \\
\cline { 3 - 7 } \multicolumn{2}{|c|}{} & F & Sig. & t & df & Sig. (2-tailed) \\
\hline \multirow{2}{*}{ TES } & Equal variances assumed & 0.047 & .669 & 2.041 & 238 & .035 \\
\cline { 2 - 7 } & Equal variances not assumed & & & 2.003 & 233.045 & .032 \\
\hline \multirow{2}{*}{ ACS } & Equal variances assumed & 0.016 & .849 & 2.031 & 238 & .027 \\
\cline { 2 - 7 } & Equal variances not assumed & & & 2.003 & 231.045 & .021 \\
\hline \multirow{2}{*}{ SOS } & Equal variances assumed & 0.032 & .518 & 3.819 & 238 & .002 \\
\cline { 2 - 7 } & Equal variances not assumed & & & 3.833 & 233.520 & .001 \\
\hline \multirow{2}{*}{ SES } & Equal variances assumed & 0.067 & .428 & 3.739 & 238 & .043 \\
\cline { 2 - 7 } & Equal variances not assumed & & & 3.853 & 234.520 & .020 \\
\hline
\end{tabular}

The null hypothesis in Levene's test is that the variances of the two populations are equal. Since pvalues are greater than $0.05(\alpha)$, we fail to reject the null hypothesis. Therefore, equal variances assumed are taken for the t-test (Table 3). Therefore, results have shown a significant difference in institutional support between the state university and private university. By observing, the mean score of the institutional support variables from a state university is greater than the mean score of the institutional support variables from a private university. In-state university it can also observe that the 
Technology Support, Social Support, Academic Support, Service Support, and Student Satisfaction

mean score of academic support $(\mathrm{M}=3.52, \mathrm{SD}=0.79)$ has scored higher compared to other variables of institutional support. In private university, it can also observe that the mean score of technology support $(\mathrm{M}=2.99, \mathrm{SD}=0.65)$ has scored higher compared to other variables of institutional support.

Table 4: The factor loading for Institutional support items

\begin{tabular}{|c|c|c|c|c|c|c|c|}
\hline \multirow{2}{*}{ Variables } & \multirow{2}{*}{$\begin{array}{l}\text { Eigen } \\
\text { Value }\end{array}$} & \multirow{2}{*}{$\begin{array}{l}\% \text { of Vari- } \\
\text { ance Ex- } \\
\text { plained }\end{array}$} & \multicolumn{4}{|c|}{ Factor Loadings } & \multirow{2}{*}{$\begin{array}{l}\text { Cronbach's } \\
\text { Alpha Value }\end{array}$} \\
\hline & & & 1 & 2 & 3 & 4 & \\
\hline \multicolumn{8}{|l|}{ Academic support } \\
\hline Financial assistance & \multirow{6}{*}{8.38} & \multirow{6}{*}{$24.54 \%$} & 0.668 & & & & \multirow{6}{*}{0.891} \\
\hline Foreign language & & & 0.637 & & & & \\
\hline Campus placements & & & 0.636 & & & & \\
\hline Industrial visits & & & 0.533 & & & & \\
\hline Coaching classes & & & 0.596 & & & & \\
\hline $\begin{array}{l}\text { Communication with } \\
\text { parents }\end{array}$ & & & 0.531 & & & & \\
\hline \multicolumn{8}{|l|}{ Technology support } \\
\hline Virtual classroom & \multirow{6}{*}{6.55} & \multirow{6}{*}{$15.25 \%$} & & 0.691 & & & \multirow{6}{*}{0.841} \\
\hline Online journals & & & & 0.639 & & & \\
\hline Dynamic website & & & & 0.635 & & & \\
\hline Biometric machine & & & & 0.509 & & & \\
\hline Soft skills program & & & & 0.588 & & & \\
\hline Advanced laboratories & & & & 0.562 & & & \\
\hline Social support & & & & & & & \\
\hline Extracurricular activities & \multirow{3}{*}{5.67} & \multirow{3}{*}{$13.67 \%$} & & & 0.733 & & \multirow[b]{3}{*}{0.786} \\
\hline Meritorious scholarship & & & & & 0.679 & & \\
\hline Team spirit & & & & & 0.558 & & \\
\hline \multicolumn{8}{|l|}{ Service support } \\
\hline Hygienic sanitary utilities & \multirow{3}{*}{3.22} & \multirow{3}{*}{$7.20 \%$} & & & & 0.652 & \multirow[b]{3}{*}{0.798} \\
\hline Hygienic canteen food & & & & & & 0.573 & \\
\hline ATM /Gym & & & & & & 0.552 & \\
\hline
\end{tabular}

Extraction Method: Principal Component Analysis.

Rotation Method: Varimax with Kaiser Normalization.

Exploratory factor analysis was used. The major function of this technique is to summarize the data collected in a large number of original items into a compact set of new factors (Hair, Black, Babin, \& Anderson, 2014, p.94). Kaiser-Meyer-Olkin Measure of Sampling Adequacy .834 is significant, Bartlett's test of sphericity was also significant $(\mathrm{p}<.001)$. All the items with factor score more than 0.50 loaded clearly on different factors (See Table5). The factor scores less than 0.50 were suppressed and varimax rotation was performed to get a clearer view of the factors. Specifically, all individual item factor loading for their respective components were above the value of 0.5 (Bagozzi \& Baumgartner, 1994; Clark \& Watson, 1995), which range from, 0.531 to 0.733 in Table 4. The factors converged in six iterations. Eigen values for ACS, TES, SOS, and SES were 8.38, 6.55, 5.67, and 3.22 respectively and the total $\%$ variance explained was $24.54,15.25,13.67$, and 7.20 respectively. The constructs were found to be reasonably distinct from each other. Pearson correlation coefficients among the study variables were calculated using SPSS and were found to be significant. The reliability coefficients Cronbach's alpha values for each scale were also more than 0.70 , which shows the questionnaire had internal consistency (Muijs, 2011). 
Kakada, Deshpande, \& Bisen

Table 5: KMO and Bartlett's Test

\begin{tabular}{lcc}
\hline \multicolumn{3}{c}{ KMO and Bartlett's Test } \\
\hline Kaiser-Meyer-Olkin Measure of Sampling Adequacy & .834 \\
& Approx. Chi-Square & 7663.211 \\
Bartlett's Test of Sphericity & df & 276 \\
& Sig. & .000 \\
\hline
\end{tabular}

The purpose of regression analysis is to relate the dependent variable to a set of independent variables. In the correlation, the relationship between two variables is computed; these variables could be independent or dependent. Correlation does not take into account the effect of the other variables, which may be contributing to this relationship. However, regression analysis partials out the effect of other variables and only a significant relationship of the independent variable with the dependent variable emerge. The collinearity statistics include the tolerance and variance inflation factor (VIF) that depicts the degree of interrelation among independent variables and the inflation of variances in the regression coefficients due to interrelation among independent variables respectively. The tolerance index should be greater than .2, and the VIF index should be less than 10 (Field, 2009). The tolerance index is .346, and the VIF index is .461, which reveals the absence of multicollinearity among the items.

Table 6: Multiple regression analysis for state university students

\begin{tabular}{|c|c|c|c|c|c|c|}
\hline \multirow[t]{2}{*}{$\begin{array}{l}\text { Dependent } \\
\text { Variable }\end{array}$} & \multirow[t]{2}{*}{$\begin{array}{l}\text { Independent } \\
\text { Variable }\end{array}$} & \multirow{2}{*}{$\begin{array}{c}\text { Standardized } \\
\text { Coefficients } \\
\text { (Beta) }\end{array}$} & \multirow{2}{*}{$\mathrm{t}$} & \multirow{2}{*}{ Sig. } & \multicolumn{2}{|c|}{$\begin{array}{c}\text { Collinearity } \\
\text { Statistics }\end{array}$} \\
\hline & & & & & $\begin{array}{l}\begin{array}{c}\text { Toler- } \\
\text { ance }\end{array}\end{array}$ & VIF \\
\hline \multirow{7}{*}{$\begin{array}{l}\text { Student } \\
\text { Satisfaction }\end{array}$} & Academic support & 0.374 & 4.524 & $0.032^{* *}$ & 0.346 & 0.461 \\
\hline & Technology support & 0.231 & 3.063 & $0.041 * *$ & 0.349 & 0.480 \\
\hline & Social support & 0.188 & 2.621 & $0.000^{* *}$ & 0.325 & 0.463 \\
\hline & Service support & 0.275 & 3.458 & $0.021 * *$ & 0.268 & 0.403 \\
\hline & & & R Square & 0.607 & & \\
\hline & & & Adjusted $\mathrm{R}^{2}$ & 0.572 & & \\
\hline & & & Sig. F Change & $0.000^{* *}$ & & \\
\hline
\end{tabular}

It is seen from Table 6 that the regression coefficient for technology, social, academic and service supportare all statistically significant. Additionally, we find that academic support has the greatest impact on student satisfaction $(\beta=0.374)$. The data also indicates that service support is the second most important element in predicting student satisfaction levels $(\beta=0.275)$. Whereas, technology support and social support show less impact on student satisfaction compared with academic and service support. Since all the p-values are less than (0.05), it shows a statistically significant impact between the variables at a 95\% confidence level. The regression model achieves a good degree of fit, as reflected by (Adj. $\mathrm{R}^{2}=0.57$ ), which asserted that $57 \%$ of the variation in overall student satisfaction was explained by the state university students. 
Table 7: Multiple regression analysis for private university students

\begin{tabular}{|c|c|c|c|c|c|c|}
\hline \multirow[t]{2}{*}{$\begin{array}{l}\text { Dependent } \\
\text { Variable }\end{array}$} & \multirow[t]{2}{*}{$\begin{array}{l}\text { Independent } \\
\text { Variable }\end{array}$} & \multirow{2}{*}{$\begin{array}{l}\text { Standardized } \\
\text { Coefficients } \\
\text { (Beta) }\end{array}$} & \multirow[t]{2}{*}{$\mathbf{t}$} & \multirow[t]{2}{*}{ Sig. } & \multicolumn{2}{|c|}{$\begin{array}{l}\text { Collinearity } \\
\text { Statistics }\end{array}$} \\
\hline & & & & & $\begin{array}{l}\text { Toler- } \\
\text { ance }\end{array}$ & VIF \\
\hline \multirow{5}{*}{$\begin{array}{l}\text { Student } \\
\text { Satisfaction }\end{array}$} & Academic support & 0.328 & 4.430 & $0.037 * *$ & 0.351 & 0.481 \\
\hline & Technology support & 0.411 & 5.740 & $0.000 * *$ & 0.369 & 0.457 \\
\hline & Social support & 0.181 & 2.570 & $0.011^{* *}$ & 0.384 & 0.483 \\
\hline & Service support & 0.193 & 3.257 & $0.001 * *$ & 0.275 & 0.459 \\
\hline & & & $\begin{array}{l}\text { R Square } \\
\text { Adjusted } \mathrm{R}^{2} \\
\text { Sig. F Change }\end{array}$ & $\begin{array}{l}0.480 \\
0.467 \\
0.000^{* *}\end{array}$ & & \\
\hline
\end{tabular}

It is seen from Table 7 that the regression coefficient for technology, social, academic and service support are all statistically significant. Additionally, we find that technology support has the greatest impact on student satisfaction $(\beta=0.411)$. The data also indicates that academic support is the second most important element in predicting student satisfaction levels $(\beta=0.328)$. Whereas, social support and service support show less impact on student satisfaction compared with academic and technology support. Since all the p-value is less than (0.05), it shows a statistically significant impact between the variables at a 95\% confidence level. The regression model achieves a good degree of fit, as reflected by (Adj. $\mathrm{R}^{2}=0.47$ ), which asserted that $47 \%$ of the variation in overall student satisfaction was explained by the private university students.

Thus, our hypotheses technology support, social support, academic support, and service support are positively and significantly related to student satisfaction were supported.

\section{DISCUSSION}

The purpose of this study was to investigate the relationship between various facets of institutional support with student satisfaction in both state and private universities. The results indicated that the institutional support dimensions - technology support, academic support, social support, and service support -are statistically positively related to student satisfaction in both state and private universities.

H1 has proved that academic support variable positively and significantly affects student satisfaction in both state and private universities. This hypothesis was supported in our findings. In state universities, the result indicated that the mean score of academic support was higher than other variables of institutional support. This result clearly shows that state university students have high academic support, which indicates a high level of motivation and skills to enhance academic output, which in turn increases student satisfaction. The study supports the work by Smayling and Millers (2012) that academic support leads to enhanced skills, ability, and academic output andfound a positive relationship with student satisfaction. Chambel and Curral (2005) found that the level of satisfaction has a direct impact on student performance, which increases through satisfaction and mediates the relationship between academic work and performance. Having financial assistance for students to attend national and international conferences, workshops, courses to learn foreign language, campus placement activities and industrial visit / guest lecturers for practical exposure and industrial training develops trust in students that leads to higher student satisfaction. Foreign language courses offering on the campus have a significant influence on student satisfaction (Ozudogru \& Hismanoglu, 2016).

The investigation of $\mathrm{H} 2$ has evidenced that technology support variable positively and significantly affects student satisfaction in both state and private universities. This hypothesis was supported in our findings. In private universities, results indicated that the mean score of technology support was scored higher compared to other variables of institutional support. These findings are in line with Suleimen (2019) that information and communication technology has a positive effect on student learning and should be included in classroom instruction. Using technology enables people to inter- 
act with each other and exchange ideas, research independently, adapt to new situations and take ownership of their learning (Miller, 2003). The current research finding supports the results of AlAzawei (2019) quality and experience antecedents on technology use and learner satisfaction and association between technology use and learner satisfaction. These results clearly show that private university students have high technology support, which indicates they are more satisfied in digital affiliation, e-classrooms and learning which in turn increase student satisfaction.

H3 has established that social support variable positively and significantly affects student satisfaction in both state and private universities. This hypothesis was supported in our findings. Students from both the universities scored social support lower compared to other variables. This shows that students are not satisfied with the social support provided by both state and private universities. From the above results, we can say that educational institute management has to pay sincere attention and focus to provide cohesive social support, which has a significant impact on student satisfaction. This statement, supported by Awang, Kutty, \& Ahmad (2014), perceived social support and well-being are related to student satisfaction. Duru's (2007) findings revealed that the level of individual life satisfaction is positively affected by social support. Social support, from either peers or family members, is related to increased well-being and academic performance (Hirsch \& Barton, 2011; Pluut, Curşeu, \&Ilies, 2015). This indicates that social support plays a vital role in explaining not only the level of satisfaction but also its impact on the life satisfaction of students in both state and private university. These lines are in support of Ozben (2013) that higher levels of satisfaction among students exist when a campus environment has a strong social life. To support students in their new campus environment, higher educational institutions must come forward to implement useful strategies and programs that promote social support among the students.

$\mathrm{H} 4$ has confirmed that the service support variable positively and significantly affects student satisfaction in both state and private universities. This hypothesis was supported in our findings. Previous studies have shown that student perception towards institutional support has a positive significant effect on student satisfaction (Clemes, Gan, Kao, \& Choong, 2008). Thus, it can be explained that the university providing clean and hygienic washrooms, sanitary utilities, and other related service support makes a student more comfortable and happy with the campus environment. Consequently, canteen food and facilities like dispensary center, ATM and gym on campus developed a sense of belongingness towards one's institution that led to higher student satisfaction.

Thus, student satisfaction increases when there is an increase in institutional support. State universities with their legacy of more than six decades have senior faculty, active participation, intervention with the government policymakers and education accreditation agencies, and positive bilateral dialogue with the industry interface which enriches the academic environment of state universities in success. Private universities scored significantly higher in technology support compared to state universities is due to their state-of-the-art facilities, advanced technological labs, free $\mathrm{Wi}$-Fi, and access to technological tools and instruments add as a unique selling point.

Technical advancements, faculty interactions, soft skills training, placement related activities and management support build confidence and a sense of belongingness about the university which in turn develops greater satisfaction in students. Digitalization, foreign language courses, hygienic environment, academic recognition, and financial assistance for academic excellence to attend international and national conferences leads to enhance the student satisfaction. These factors enable students to bond more with the campus environment and develop trust towards university, which automatically widens the level of satisfaction. Hence, there is a positive relationship exists between institutional support and student satisfaction in both state and private university students, but comparatively state university students are more satisfied with institutional support than private university students.

As such, universities need to keep an eye out for students who may otherwise fall through the cracks of the higher education system, so that they may help them navigate the process of gaining 
access to any institutional support they may need to achieve their potential in higher education. The above findings make it clear that many higher education students with institutional support would benefit from additional support from their institutions of higher education in academic, social, technology, and service domains. Such support could go a long way in helping students to become fully integrated into their campus environment and succeed while enrolled in higher education. Additional data collection efforts to increase the sample size and different geographical samples are needed to improve the interpretation of these findings and are currently in progress. Moreover, the perspectives of parents, stakeholders, and policymakers both within and outside the higher education settings present important areas in need of further exploration.

\section{IMPLICATIONS OF THE STUDY}

The findings of the study have contributed to the body of knowledge that might help to realize the current condition of university higher education and to understand the challenges that academicpractitionersare facing to satisfy students' needs. This knowledge has some implications for the policymakers and administrators, and stakeholders in the university. In addition, the limitation of the current study in some respects does not allow generalizing the findings to the whole population of India, although the results of the study may apply to all state and private universities in India. The changing social and demographic drift of higher education institutions also increases the competitive demand and needs of student in the sphere of Indian higher education institutions. These changes can be accomplished through understanding the expectations of students and their significance placed by them on campus. The present study acknowledged that student perception about the campus environment regarding institutional support is a key antecedent to student satisfaction, which conveys that institutional support is an important component.

Secondly, stakeholders can use this finding for designing and developing a support system for students in their formative and summative assessments and select the best feedback strategies for their enhancement of satisfaction level. In addition, the results of the current study indicate that to satisfy talented and skilled students, educational institutions need to use institutional support factors to enhance the level of satisfaction. Therefore, higher educational institutions management may consider how these essential factors can influence the institutional support in enhancing student satisfaction. The major contribution of the current study to the student satisfaction literature is that the outcome suggests the differential effects of institutional support dimensions on student satisfaction. The findings of this study are important in both the theory and methodology of measuring student satisfaction. The current study presents a most recent effort and useful insights on the multifaceted nature of the institutional support in students in universities.

\section{LIMITATION AND FUTURE RESEARCH}

Although this study has provided some interesting findings for universities about how student perception of their campus environment leads to their enhancement of satisfaction, there are still some limitations of this research. Primary, this research is conducted in only two universities with the same geographic area so the findings may differ if the sample is altered. Subsequent, this study was conducted at a single point of time so the findings also may change if the study was conducted at some other point in time. Further, the fact that the study is cross-sectional may suffer from some assumptions, which can be overcome in a longitudinal study. Due to the limitation of this research, we recommend conducting further research in terms of a longitudinal study with different geographic areas and samples. Therefore, this research also recommends exploring other potential variables, which affect student satisfaction.

\section{CONCLUSION}

The purpose of the study was to investigate the influence of technology support, social support, academic support, and service support on student satisfaction in private and state universities. The 
findings of this research identified a significant relationship between institutional support dimensions and student satisfaction in state and private university in central India. This could imply that institutional support can increase the level of satisfaction in contemporary higher education. Therefore, these factors should be pursued to offer more practical and interesting educational services. Second, this research indicates that stakeholders such as administrators, faculty members, and support personnel should be careful to include institutional support factors that are the determinants of student satisfaction and benefits for university growth and development. The significant influence of the dimensions investigated here could help shape strategies and approaches to enhancing student satisfaction implementation in educational institutions.

\section{REFERENCES}

Al-Azawei, A. (2019). What drives successful social media in education and e-learning? A comparative study on Facebook and Moodle. Journal of Information Technology Education: Research, 18, 253-274. https://doi.org/10.28945/4360

Alzamel, S. (2014). Factors that influence student satisfaction with international programs in institutions of higher education: A proposed case study of the University of Dayton. International Journal of Global Business, $7(1), 15-24$.

Aroury, N., Daou, L., \&Khoury, C. E. L. (2014). University image and its relationship to student satisfaction Case of the Middle Eastern private business schools. International Strategic Management Review, 2(1), 1-8. https://doi.org/10.1016/i.ism.2014.07.001.

Astin, A. W. (1991). The changing American college student: Implications for educational policy and practice. Higher Education, 22(2), 129-143. https://doi.org/10.1007/BF00137472

Astin, A., \& Oseguera L. (2005). Degree attainment rates at American colleges and universities. Los Angeles, Higher Education Research Institute, University of California.

Awang, M. M. (2012). An exploration of strategies used by Malaysian secondary teachers for promoting positive behavior, professionals and pupils' perspectives. Doctoral Dissertation.Nethergate, Dundee:University of Dundee. Retrieved from https://discovery.dundee.ac.uk/en/studentTheses/an-exploration-of-strategies-used-bymalaysian-secondary-school-t

Awang, M. M., Ahmad, A. R., Bakar, N. A., Ghani, S. A., Saad, C. P., Husin, S., Hashim, Z., Ibrahim, M. A. H., \& Alfitri, A. (2014). Examining gaps between students' expectations and experiences at a private university. Mediterranean Journal of Social Sciences, 5(8), 396-401. Retrieved from http://www.mcser.org/journal/index.php/mjss/article/download/2571/2539

Awang, M. M., Kutty, F. M., \& Ahmad, A. R. (2014). Perceived social support and well being: The first-year student experience in university. International Education Studies, 7(13), 261-270.

https://doi.org/10.5539/ies.v7n13p261

Ayuni, D., \&Mulyana, A. (2019). Applying the service quality model as a determinant of success in e-learning: The role of institutional support and outcome value. Review of Integrative Business and Economics Research, 8, 145-159. Retrieved from http://buscompress.com/uploads/3/4/9/8/34980536/riber 8-s1 12 s18031_145-159.pdf

Baeten, M., Kyndt, E., Struyven, K., \&Dochy, F. (2010). Using student-centered learning environments to stimulate deep approaches to learning: Factors encouraging or discouraging their effectiveness. Educational Research Review, 5(3), 243-260. https://doi.org/10.1016/j.edurev.2010.06.001

Bagozzi, R. P., \& Baumgartner, H. (1994). The evaluation of structural equation models and hypothesis testing. Principles of Marketing Research, 1(10), 386-422. Retrieved from https://scinapse.io/papers/123141594

Bean, J. P. (2005). Nine themes of college student retention. In A. Seidman (Ed.).College student retention: Formula for student success (pp. 215-243). Westport, Connecticut: Greenwood Publishing Group.

Belanger, F., \& Jordan, D. H. (2000). Evaluation and implementation of distance learning: Technologies, Tools, and Techniques. Hershey, PA: Idea Group Publishing. https://doi.org/10.4018/978-1-878289-63-6 
Technology Support, Social Support, Academic Support, Service Support, and Student Satisfaction

Berenson, M., Levine, D., Szabat, K. A., \&Krehbiel, T. C. (2012). Basic business statistics: Concepts and applications. Pearson Higher Education AU.

Bergmark, U., \& Westman, S. (2016). Co-creating curriculum in higher education: Promoting democratic values and a multidimensional view on learning. International Journal for Academic Development, 21(1), 28-40. https://doi.org/10.1080/1360144X.2015.1120734

Bettinger, E. P., \& Rachel, B. B. (2014). The effects of student coaching: An evaluation of a randomized experiment in student advising. Educational Evaluation and Policy Analysis, 36(1) 3-19. https://doi.org/10.3102/0162373713500523

Bisen, S. S., \& Deshpande, Y. M. (2018). Understanding internet addiction: A comprehensive review. Mental Health Review Journal, 23(3), 165-184. https://doi.org/10.1108/mhrj-07-2017-0023

Bolliger, D. U. (2004). Key factors for determining student satisfaction in online courses. International Journal on E-learning, 3(1), 61-67. Retrieved from https://www.learntechlib.org/primary/p/2226/article 2226.pdf

Bryman, A. (2008). Of methods and methodology. Qualitative Research in Organizations and Management: An International Journal, 3(2), 159-168.

Bunce, L., Baird, A., \& Jones, S. E. (2017). The student-as-consumer approach in higher education and its effects on academic performance. Studies in Higher Education, 42(11), 1958-1978. https://doi.org/10.1080/03075079.2015.1127908

Carey, K., Cambiano, R. L., \& De Vore, J. B. (2002). Student to faculty satisfaction at a Midwestern university in the United States. InProceedings of the 25th HERSDA Annual Conference (pp. 92-97). Retrieved from https://www.herdsa.org.au/system/files/Carey.pdf

Chambel, M. J., \&Curral, L. (2005). Stress in academic life: Work characteristics as predictors of student well-being and performance. Applied Psychology, 54(1), 135-147. https://doi.org/10.1111/j.1464$\underline{0597.2005 .00200 . x}$

Chen, S. Y., \&Macredie, R. D. (2004).Cognitive modeling of student learning in web-based instructional programs. International Journal of Human-Computer Interaction, 17(3), 375-402. https://doi.org/10.1207/s15327590ijhc1703 5

Clark, L. A., \& Watson, D. (1995).Constructing validity: Basic issues in objective scale development. Psychological Assessment, 7(3), 309-319. https://doi.org/10.1037/1040-3590.7.3.309

Clemes, M. D., Gan, C., Kao, T. H., \& Choong, M. (2008). An empirical analysis of customer satisfaction in international air travel. Innovative Marketing, 4(2), 50-62. Retrieved from https://businessperspectives.org/images/pdf/applications/publishing/templates/article/assets/2229/IM en 20082 Clemes.pdf

Cotton, S., Dollard, M., \& de Jonge, J. (2002). Stress and student job design: Satisfaction, well-being, and performance in university students. International Journal of Stress Management, 9(3), 147-162. Retrieved from http:/ / citeseerx.ist.psu.edu/viewdoc/download?doi=10.1.1.506.8633\&rep=rep1\&type $=$ pdf

Courduff, J. (2011). One size never fits all: Techintegration for special needs. Learning \& Leading with Technology, 38(8), 16-19. Retrieved from https:// files.eric.ed.gov/fulltext/EJ935415.pdf

Demaray, M. K., Malecki, C. K., Davidson, L. M., Hodgson, K. K., \& Rebus, P. J. (2005). The relationship between social support and student adjustment: A longitudinal analysis. Psychology in the Schools, 42(7), 691-706. https://doi.org/10.1002/pits.20120

Denscombe, M. (2010).The good research guide for small-scale research projects. Glasgow, UK: McGraw-Hill Open University Press.

Denson, N., \& Zhang, S. (2010). The impact of student experiences with diversity on developing graduate attributes. Studies in Higher Education, 35(5), 529-543. https://doi.org/10.1080/03075070903222658

DeShields, O. W., Jr., Kara, A., \& Kaynak, E. (2005). Determinants of business student satisfaction and retention in higher education: Applying Herzberg's two-factor theory. International Journal of Educational Management, 19(2), 128-139. https://doi.org/10.1108/09513540510582426 
Duru, E. (2007). Re-examination of the psychometric characteristics of the multidimensional scale of perceived social support among Turkish university students. Social Behavior and Personality: An International Journal, 35(4), 443-452. https://doi.org/10.2224/sbp.2007.35.4.443

Ekinci, Y. (2003). An investigation of the determinants of customer satisfaction. Tourism Analysis, 8(2-4), 193196. https://doi.org/10.3727/108354203774076724

Elliot, K. M. (2002). Key determinants of student satisfaction. Journal of College Student Retention: Research, Theory \& Practice, 4(3), 271-279. https://doi.org/10.2190/B2V7-R91M-6WXR-KCCR

Elliot, K. M., \& Shin, D. (2002). Student satisfaction: An alternative approach to assessing this important concept. Journal of Higher Education Policy and Management, 24(2), 197-209. https://doi.org/10.1080/1360080022000013518

Etikan, I., Musa, S. A., \& Alkassim, R. S. (2016). Comparison of convenience sampling and purposive sampling. American Journal of Theoretical and Applied Statistics, 5(1), 1-4. https://doi.org/10.11648/j.ajtas.20160501.11

Field, A. (2009). Discovering statistics using SPSS. Thousand Oaks, CA: Sage Publications.

Gilboy, M. B., Heinerichs, S., \&Pazzaglia, G. (2015). Enhancing student engagement using the flipped classroom. Journal of Nutrition Education and Behavior, 47(1), 109-114. https://doi.org/10.1016/j.jneb.2014.08.008

Grönroos, C. (1984). A service quality model and its marketing implications. European Journal of Marketing, 18(4), 36-44. https://doi.org/10.1108/EUM0000000004784

Gulley, O. D., \& Jackson, A. L. (2016). A case study on using instructor-recorded videos in an upper-level economics course. International Review of Economics Education, 23, 28-33. https://doi.org/10.1016/i.iree.2016.06.004

Hair, J. F., Jr., Black, W. C., Babin B. J., \& Anderson, R. E. (2014). Multivariate data analysis. Harlow, Essex: Pearson Education Limited. Retrieved from https://is.muni.cz/el/1423/podzim2017/PSY028/um/ Hair Multivariate data analysis 7 th revised.pdf

Harmon, H. A., \& Wales, B. A. (1999). International and domestic students' perception of library personnel and resources. Journal of Teaching in International Business, 10(3-4), 129-148. https://doi.org/10.1300/J066v10n03 09

Hepplestone, S., Holden, G., Irwin, B., Parkin, H. J., \& Thorpe, L. (2011). Using technology to encourage student engagement with feedback: A literature review. Research in Learning Technology, 19(2), 117-127. https://doi.org/10.3402/rlt.v19i2.10347

Heyneman, S. P. (2001). The growing international market for education goods and services. International Journal of Education Development, 21(4), 345-361. https://doi.org/10.1016/S0738-0593(00)00056-0

Hirsch, J. K., \& Barton, A. L. (2011). Positive social support, negative social exchanges, and suicidal behavior in college students. Journal of American College Health, 59(5), 393-398. https://doi.org/10.1080/07448481.2010.515635

Hom, W. C. (2002). Applying customer satisfaction theory to community college planning of counselling services. IJournal, 2. Retrieved January 07, 2004, from https://eric.ed.gov/?id=ED481317

Kakada, P., \& Deshpande, Y. M. (2019). Working conditions and effective supervision: Does it matter for engineering faculty job satisfaction. The International Journal of Electrical Engineering \& Education. https://doi.org/10.1177\%2F0020720918815998

Kara, A., \&DeShields, O. W., Jr. (2004). Business student satisfaction, intentions, and retention in higher education: An empirical investigation. Marketing Educator Quarterly, 3(1), 1-25. Retrieved from http://www.academia.edu/download/34076194/student satisfaction.pdf

Kotler, P., \&. Fox, K. F. A. (1995). Strategic Marketing for Education Institutions (2nd Ed.). Prentice Hall.

Kraft, M. A., \& Dougherty, S. M. (2013). The effect of teacher-family communication on student engagement: Evidence from a randomized field experiment. Journal of Research on Educational Effectiveness, 6(3), $199-222$. https://doi.org/10.1080/19345747.2012.743636 
Technology Support, Social Support, Academic Support, Service Support, and Student Satisfaction

Leedy, P. D., \& Ormrod, J. E. (2001). Practical research: Planning and design (7th ed.). New Jersey, USA: Merrill Prentice Hall.

Lin, Y. N. (2010). Taiwanese university students' perception of university life. Counseling Psychology Quarterly, 23(2), 189-202. https://doi.org/10.1080/09515071003798220

Lipka, O., Forkosh B. A., \& Meer, Y. (2019). Academic support model for post-secondary school students with learning disabilities: Student and instructor perceptions. International Journal of Inclusive Education, 23(2), 142157. https://doi.org/10.1080/13603116.2018.1427151

Loveland, K. A., \& Bland, E. (2013). Impact of course scheduling formats on student learning and satisfaction. Atlantic economic journal, 41(2), 191-192.

Martirosyan, N. M., Saxon, D. P., \&Wanjohi, R. (2014). Student satisfaction and academic performance in Armenian higher education. American International Journal of Contemporary Research, 4(2), 1-5. Retrieved from http://www.aijcrnet.com/journals/Vol 4 No 2 February 2014/1.pdf

Massimo, P. (2014). Multidimensional analysis applied to the quality of the websites: Some empirical evidence from the Italian public sector. Economics and Sociology, 7(4), 128-138. https://doi.org/10.14254/2071789X.2014/7-4/9

McLaughlin, J. E., Roth, M. T., Glatt, D. M., Gharkholonarehe, N., Davidson, C. A., Griffin, L. M., Esserman, D., \& Mumper, R. J. (2014). The flipped classroom: A course redesign to foster learning and engagement in a health professions school. Academic Medicine, 89(2), 236-243. https://doi.org/10.1097/ACM.0000000000000086

Miller, R. (2003). Student satisfaction and institutional success. Paper presented at the 43rd Annual AIR Forum, Tampa, FL.

Ministry of Human Resource Development. (2018). All India survey on higher education. Retrieved from http://aishe.nic.in/aishe/viewDocument.action?documentId=263

Muijs, D. (2011). Doing quantitative research in education with SPSS (2nd ed.).Thousand Oaks, CA: SAGE Publications. https://doi.org/10.4135/9781849203241

Navarro, M. M., Iglesias, P. M., \&Torres, R. P. (2005). A new management element for universities: Satisfaction with the offered courses. International Journal of Educational Management, 19(6), 505-526. https://doi.org/10.1108/09513540510617454

Nulty, D. D. (2008). The adequacy of response rates to online and paper surveys: What can be done? Assessment \& Evaluation in Higher Education, 33(3), 301-314. https://doi.org/10.1080/02602930701293231

Nyer, P. U. (2000). An investigation into whether complaining can cause increased consumer satisfaction. Journal of Consumer Marketing, 17(1), 9-19. https://doi.org/10.1108/07363760010309500

O’Neill, M. A., \&Palmer, A. (2004). Importance-performance analysis: A useful tool for directing continuous quality improvement in higher education. Quality Assurance in Education, 12(1), 39-52. https://doi.org/10.1108/09684880410517423

Oldfield, B. M., \& Baron, S. (2000). Student's perception of service quality in a UK university business and management faculty. Quality Assurance in Education, 8(2), 85-95. https://doi.org/10.1108/09684880010325600

Ostergaard, P., \&Kristensen, K. (2005).Drivers of student satisfaction and loyalty at different levels of higher education. The Aarbus School of Business, 6(1), 145-152. Retrieved from https://pure.au.dk/portal/files/214/PAPER SRHE 2005 SESSION PAPER 6.31.PDF

Ozben, S. (2013).Social skills, life satisfaction, and loneliness in Turkish university students. Social Behavior and Personality: An International Journal, 41(2), 203-213. https://doi.org/10.2224/sbp.2013.41.2.203

Ozudogru, F., \& Hismanoglu, M. (2016). Views of freshmen students on foreign language courses delivered via e-learning. Turkish Online Journal of Distance Education, 17(1), 31-47. https://doi.org/10.17718/tojde.18660

Pallant, J. (2013). SPSS survival manual: A step by step guide to data analysis using IBM SPSS (5th ed.). Maidenhead, UK: McGraw-Hill Education, Open University Press. 
Pareek, L. U., \&Purohit, S. (2018). Training Instruments in HRD and OD. SAGE Publishing India.

Paul, R., \& Pradhan, S. (2019). Achieving student satisfaction and student loyalty in higher education: A focus on service value dimensions. Services Marketing Quarterly, 40(3), 245-268. https://doi.org/10.1080/15332969.2019.1630177

Pluut, H., Curşeu, P. L., \&Ilies, R. (2015). Social and study-related stressors and resources among university entrants: Effects on well-being and academic performance. Learning and Individual Differences, 37, 262268. https://doi.org/10.1016/j.lindif.2014.11.018

Price, L., \& Kirkwood, A. (2011). Enhancing professional learning and teaching through technology: A synthesis of evidencebased practice among teachers in higher education. Heslington, York: High Education Academy. Retrieved from http://oro.open.ac.uk/30686/4/1 PLATP main report.pdf

Priya, R. S., Bhadouria, S., \& Charu, S. (2013). An empirical study on the satisfaction level of students from the technical institution. SIES Journal of Management, 9(2), 24-46.

Rittschof, K., \& Chambers, W. (2011). Modern measurement information graphics for understanding student performance differences. International Journal of Teaching and Learning in Higher Education, 23(3), 350-362. Retrieved from https:// files.eric.ed.gov/fulltext/EJ946161.pdf

Roach, T. (2014). Student perceptions toward flipped learning: New methods to increase interaction and active learning in economics. International Review of Economics Education, 17, 74-84. https://doi.org/10.1016/i.iree.2014.08.003

Roberts, J., \& Styron, R., Jr. (2010). Student satisfaction and persistence, factors vital to student retention. Research in Higher Education, 6, 1-18. Retrieved from http:/ / citeseerx.ist.psu.edu/viewdoc/download?doi=10.1.1.567.1903\&rep=rep1\&type $=$ pdf

Rode, J. C., Arthaud-Day, M. L., Mooney, C. H., Near, J. P., Baldwin, T. T., Bommer, W. H., \& Rubin, R. S. (2005). Life satisfaction and student performance. Academy of Management Learning\& Education, 4(4), 421433. https://doi.org/10.5465/amle.2005.19086784

Saenz, T., Marcoulides, G., Junn, E., \& Young, R. (1999).The relationship between the college experience and academic performance among minority students. International Journal of Educational Management, 13(4), 199208. https://doi.org/10.1108/09513549910278124

Sahin, I., \& Shelley, M. C. (2008).Considering students' perceptions: The distance education student satisfaction model. Educational Technology \& Society, 11(3), 216. Retrieved from https://lib.dr.iastate.edu/cgi/viewcontent.cgi?article $=1006 \&$ context $=$ pols pubs

Saunders, M., Lewis, P., \& Thornhill, A. (2009). Research methods for business students (5th ed.). London, UK: Pearson Education.

Schertzer, C. B., \&Schertzer, S. M. B. (2004). Student satisfaction and retention: A conceptual model. Journal of Marketing for Higher Education, 14(1), 79-91. https://doi.org/10.1300/J050v14n01 05

Smayling, M., \& Miller, H. (2012). Job satisfaction and job performance at the internship level. Journal of Leadership, Accountability, and Ethics, 9(1), 27-33. Retrieved from http://t.www.nabusinesspress.com/JLAE/SmaylingM Web9 1 .pdf

Smith, R., \& Ennew, C. (2001). Service quality and its impact on word-of-mouth communication in higher education. Research Paper Series. Selangor, Malaysia: The University of Nottingham in Malaysia, Division of Business and Management.

Suleimen, N. (2019). Appraising the attitude towards information communication technology integration and usage in Kazakhstani higher education curriculum. Journal of Information Technology Education: Research, 18, 355-378. https://doi.org/10.28945/4403

Tarhini, A., Hone, K., \& Liu, X. (2015). A cross-cultural examination of the impact of social, organizational and individual factors on educational technology acceptance between British and Lebanese university students. British Journal of Educational Technology, 46(4), 739-755. https://doi.org/10.1111/bjet.12169 
Technology Support, Social Support, Academic Support, Service Support, and Student Satisfaction

Topping, K. J., \& Foggie, J. (2010). Interactive behaviors for building independence in exceptional youth. In D. Jindal-Snape (Ed.), Educational transitions: Moving stories from around the world (pp. 161-165). New York: Routledge. https://doi.org/10.4324/9780203859124

Umbach, P., \& Porter, S. (2002). How do academic departments impact student satisfaction? Understanding the contextual effects of departments. Research in Higher Education, 43(2), 209-234. https://doi.org/10.1023/A:1014471708162

Vaatstra, R., \& De Vries, R. (2007). The effect of the learning environment on competences and training for the workplace according to graduates. Higher Education, 53(3), 335-357. https://doi.org/10.1007/s10734$\underline{005-2413-4}$

Wilkins, S., Stephens, B. M., \& Huisman, J. (2012).Student satisfaction and student perceptions of quality at international branch campuses in the United Arab Emirates. Journal of Higher Education Policy and Management, 34(5), 543-556. https://doi.org/10.1080/1360080X.2012.716003

William, J. (2002). The student satisfaction approach: Student feedback and its potential role in quality assessment and enhancement. Presented at the24th EAIR Forum, Prague.

Yorke, M., \& Thomas, L. (2003). Improving the retention of students from lower socio-economic groups. Journal of Higher Education Policy and Management, 25(1), 63-74. https://doi.org/10.1080/13600800305737

\section{APPENDIX: THE RESEARCH QUESTIONNAIRE}

\begin{tabular}{|c|c|c|c|c|c|c|}
\hline $\begin{array}{l}\text { Sr. } \\
\text { No. }\end{array}$ & STATEMENT & $\begin{array}{c}\text { Strongly } \\
\text { Agree }\end{array}$ & Agree & $\begin{array}{l}\text { Unde- } \\
\text { cided }\end{array}$ & $\begin{array}{l}\text { Disa- } \\
\text { gree }\end{array}$ & $\begin{array}{l}\text { Strongly } \\
\text { Disagree }\end{array}$ \\
\hline 1. & $\begin{array}{l}\text { My Institute provides free access to Online jour- } \\
\text { nals on campus to study. }\end{array}$ & & & & & \\
\hline 2. & $\begin{array}{l}\text { My Institute has a virtual classroom for broad- } \\
\text { casting academic innovative documentaries }\end{array}$ & & & & & \\
\hline 3. & $\begin{array}{l}\text { My Institute has a dynamic website to view/ } \\
\text { share academic events, Notifications, news up- } \\
\text { dates, and announcements. }\end{array}$ & & & & & \\
\hline 4. & $\begin{array}{l}\text { I feel a biometric machine is essential for main- } \\
\text { taining students' attendance. }\end{array}$ & & & & & \\
\hline 5. & $\begin{array}{l}\text { My Institute provides financial assistance for } \\
\text { students to attend national and international } \\
\text { conferences, workshops, and academic events. }\end{array}$ & & & & & \\
\hline 6. & $\begin{array}{l}\text { My Institute offers a course to learn a foreign } \\
\text { language. }\end{array}$ & & & & & \\
\hline 7. & $\begin{array}{l}\text { Students are encouraged to take initiative in } \\
\text { sports, technical and other extracurricular activi- } \\
\text { ties. }\end{array}$ & & & & & \\
\hline 8. & $\begin{array}{l}\text { My Institute encourages students by giving re- } \\
\text { wards, recognition, and meritorious scholarship } \\
\text { for excellence in academics. }\end{array}$ & & & & & \\
\hline 9. & $\begin{array}{l}\text { My Institute provides a placement related /soft } \\
\text { skills training program to enhance technical and } \\
\text { personnel skills. }\end{array}$ & & & & & \\
\hline 10. & $\begin{array}{l}\text { Campus placement activities are well planned } \\
\text { here. }\end{array}$ & & & & & \\
\hline
\end{tabular}


Kakada, Deshpande, \& Bisen

\begin{tabular}{|c|c|c|c|c|c|c|}
\hline $\begin{array}{l}\text { Sr. } \\
\text { No. }\end{array}$ & STATEMENT & $\begin{array}{l}\text { Strongly } \\
\text { Agree }\end{array}$ & Agree & $\begin{array}{l}\text { Unde- } \\
\text { cided }\end{array}$ & $\begin{array}{l}\text { Disa- } \\
\text { gree }\end{array}$ & $\begin{array}{l}\text { Strongly } \\
\text { Disagree }\end{array}$ \\
\hline 11. & $\begin{array}{l}\text { My institute provides local industrial visit /guest } \\
\text { lecturers for practical exposure and industrial } \\
\text { training. }\end{array}$ & & & & & \\
\hline 12. & $\begin{array}{l}\text { The laboratories are well equipped and main- } \\
\text { tained in my college. }\end{array}$ & & & & & \\
\hline 13. & $\begin{array}{l}\text { My college has a high degree of team spirit } \\
\text { among the students. }\end{array}$ & & & & & \\
\hline 14. & $\begin{array}{l}\text { There is high interdepartmental collaboration in } \\
\text { my institution. }\end{array}$ & & & & & \\
\hline 15. & $\begin{array}{l}\text { My institute provides GATE coaching classes for } \\
\text { higher studies. }\end{array}$ & & & & & \\
\hline 16. & $\begin{array}{l}\text { I feel college washrooms and sanitary utilities are } \\
\text { clean and hygienic }\end{array}$ & & & & & \\
\hline 17. & The canteen food is good and hygienic. & & & & & \\
\hline 18. & $\begin{array}{l}\text { I feel happy to send or recommend my siblings } \\
\text { or relatives to this college to study. }\end{array}$ & & & & & \\
\hline 19. & $\begin{array}{l}\text { My college communicates regularly with my par- } \\
\text { ents related to academic performance \& personal } \\
\text { well-being. }\end{array}$ & & & & & \\
\hline 20. & $\begin{array}{l}\text { My institute has facilities like (Dispensary cen- } \\
\text { ter/ATM / Gym). }\end{array}$ & & & & & \\
\hline 21. & $\begin{array}{l}\text { Overall, my experience is satisfactory in this col- } \\
\text { lege. }\end{array}$ & & & & & \\
\hline
\end{tabular}

\section{BIOGRAPHIES}

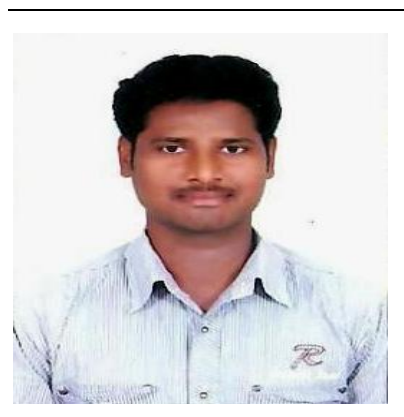

Praveen Kakada holds a PhD from Visvesvaraya National Institute of Technology, Nagpur, India. He is a teaching assistant in communication skills. His areas of research interest focuses on information and communication technology (ICT), faculty and student satisfaction in higher education. He has presented papers in national and international conferences on ICT in education.

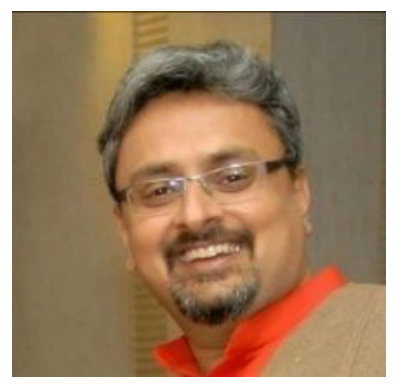

Yogesh Deshpande is professor in the Department of Humanities and Social Sciences in Visvesvaraya National Institute of Technology, Nagpur (India). His area of interest is positive psychology, information technology, and human values in higher education. He was an associate dean in public relations and administration affairs in VNIT, Nagpur, India. Currently is the head of the department and he has published papers in reputed journals. 


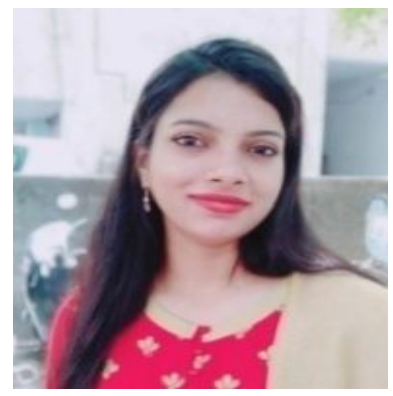

Shilpa Bisen holds a Master's degree in clinical psychology from the university of Pune (India) and doctorate from Visvesvaraya National Institute of Technology, Nagpur (India). Her research interest is in the area of information and communication technology addiction, utilization of web based application and e-learning in classrooms. She has published papers widely in international journals and presented a number of conference papers. 